\section{TO CORRESPONDENTS}

Medicus.-We think our correspondent did not see the exact import of our remarks. The College of Physicians certainly has the right of giving a license to practise to whomsoever it pleases; but we contend that it certainly has not the right of conferring the title of Doctor of Medicine. Medicus will, no doubt, readily admit that there is some difference between these two things. The title of M.D. is an academical distinction, conferred by some university on those who have pursued a certain course of study, and passed certain examinations, within its walls. But the possession of this title confers no right to practise as a physician; in fact, as Medicus expresses it, "no person whatever (be he a graduate in medicine of any university, however famous) possesses a legal right to practise as a physician in England," with the exception only of graduates of Oxford and Cambridge; all others must be licensed by the London College of Physicians before they can practise in any part of England; and even the Oxford and Cambridge doctors must procure that license if they wish to practise in London, or within seven miles thereof. Since, then, according to the customs heretofore existing, a physician was a man possessing the academical title of M.D., and a license to practise also, and since the College of Physicians, although they can confer the latter, certainly have no power to grant the former, we think our correspondent will admit that our original assertion was correct. We speak, of course, of the law as it exists, but without contending that it is well adapted to the present state of society. We may add, that a precisely similar distinction between the possession of a title and the right to exercise it exists in the church as in medicine. The Church of England recognises the orders of the churches of Rome, Greece, America, and Syria; but yet the clergy ordained in those churches cannot exercise their vocation here without a license from the bishop.

Discipulus.-We have received a long letter from some enthusiastic boy, smarting under the grievances, real and imaginary, which he endures during the term of his apprenticeship. He complains of the neglect of masters who leave their pupils to acquire their professional knowledge as they best may, without taking the trouble to direct them in their course of reading, or to explain to them the nature of the cases which they witness, and the principles on which they are treated. But, more especially, he complains of the petty indignities often inflicted on medical pupils by the mistress of the establishment. We well know how difficult it must be for a youth of spirit to endure the domestic tyranny of a woman who has neither liberality of conduct nor lady-like feeling, and how heavily responsible those persons are for the future misconduct of young men, who give them the strongest inducement to seek the pleasures of debauchery abroad, by denying them the comforts and happiness to which they are entitled at home. Yet we would counsel our youthful correspondent to submit with a good grace, to do his duty, and to revenge himself by showing a better example.
C. $R$. - The account is, we think, moderate, and such as any jury would allow; except, perhaps, that the charges for attendance on servants ought not quite to equal those for their superiors.

Immediate attention shall be given to the communication from Manchester.

Communications have been received from $M r$. Newnham, Farnham; Dr. Oke, Southampton; Dr. Starr, Kettering; Dr. Favell, Sheffield, \&c. We shall endeavour to make room for the greater part of them next week.

A.-The suggestion relative to the fellowship is hardly worth attending to.

*** Communications, journals, and books for review, to be forwarded (carriage paid) to the Publisher, 356 , Strand, London. Letters connected with the Provincial Association, to Dr. Streeten, Worcester.

Gentlemen desirous of having the "Provincial Medical Journal," forwarded to them by post, may send a post-office order to the Publisher, 356, Strand, London.

\begin{tabular}{|c|c|c|c|c|}
\hline \multirow{3}{*}{$\begin{array}{l}\text { One Year } \\
\text { Six Months }\end{array}$} & \multicolumn{2}{|c|}{ TERMS. } & & Unstamped. \\
\hline & .. $£ 110$ & 0 & -・ & $\ldots £ 1 \quad 60$ \\
\hline & s.. $\quad 015$ & 0 & .. & $\begin{array}{llll}\ldots & 0 & 13 & 0\end{array}$ \\
\hline
\end{tabular}

\section{ERRATA.}

In last Number, page 461, col. J, line 22, for "Maitre Jan," read Maitre Jean; line 39, for "Walthen," read Walther.

THE FRIENDS' RETREAT, YORK.In consequence of recent alterations in this Establishment, there are at present several vacancies for Patients of the higher class, without limitation to the Society of Friends, at from Two to Five Guineas a Week.

Applications may be addressed to the Superintendent of the Retreat, York.

\section{DR. MARTIN H. LYNCH'S NEW VAPOR} BATH.

J. MORRIS, IRONMONGER and U. MANUFACTURER of WARM VAPOR and SHOWER BATHS, begs leave respectfully to inform Gentlemen of the Medical Profession, and especially the Members of the Provincial Medical and Surgical Association, that he is now prepared to forward the above useful and simple Apparatus in Copper and T'in, including Dr. Lynch's recently in vented Diffuser, by which the foot-bath is dispensed with, the entire supply of vapor being conveyed through the Diffuser, which forms a footstool, and by means of which the great desideratum in such baths is completely achieved-namely, the production of perspiration in the feet as profuse as in the neck and chest. PRICES FOR CASI : $f s$. $d$.

Strong Tin Boiler and Pipes, with Stand and Lamp, Diffuser, and Packing-case . . $017 \quad 0$ Copper Boiler and Pipes, with Stand and

Lamp, Diffuser, and Box, with Lock, \&c. 110 Fine Canvas Cloak ............. 1 00 Portable Stool, with Eight Shifting Legs and Hoop, Brass Fastenings, and Thumb Screws, \&c. ............... 0186 C. J. Morris, 32, Parliament-street. 